\title{
Complicações de distocia em égua e potro: prolapso uterino, agalactia, síndrome do mau ajustamento e hérnia diafragmática - relato de caso
}

Pedro Henrique Salles Brito, Marilia Alves Ferreira, Gonçalo da Rocha Morona, Gustavo Morandini Reginato, Julia de Assis Arantes, Roberto do Prado Filho Romano, Paulo Fantinato Neto, Renata Gebara Sampaio Dória

Universidade São Paulo (USP), Pirassununga, SP, Brasil

*Autor correspondente

e-mail: pedro.brito@usp.br

\section{Resumo}

Distocias representam menos de $1 \%$ de todos os partos e podem gerar consequências graves para a égua, como ruptura uterina, hemorragia de artéria uterina, laceração de cervix ou vagina, prolapso uterino e também prejuízos à vitalidade do potro, predispondo à síndrome do mau ajustamento, hérnia diafragmática de origem traumática, evisceração, fraturas, entre outros. Foi encaminhada à Unidade Didática Clínico Hospitalar (UDCH) da FZEA/USP uma égua, 7 anos, apresentando prolapso uterino, 6 horas após o parto. Segundo responsável, o animal encontrava-se em decúbito lateral há dois dias, sem sinais de parto e, durante o exame transvaginal, ocorreu ruptura dos anexos fetais e indução involuntária do parto. Houve grande dificuldade para a remoção do feto e após 30 minutos de tentativas, conseguiram finalizar o parto ainda na fazenda. Seis horas após o parto, ocorreu prolapso uterino, o que levou ao encaminhamento para à UDCH. Após lavagem uterina e realização de crioterapia, sob sedação e anestesia epidural, reposicionou-se o útero na cavidade pélvica e everteu-se ambos os cornos uterinos. Durante o pós-operatório, tratou-se o útero com lavagem uterina, duas vezes ao dia, com solução Ringer Lactato à 5\% de iodo, Gentamicina 6,6 mg/Kg SID por 5 dias, Penicilina Potássica 22.000 UI/Kg QID por 10 dias e Flunixim Meglumine 1,1 mg/Kg SID por 5 dias. Observou-se que a égua não havia produzido colostro e a potra ainda não havia mamado. Iniciou-se o tratamento com domperidona $500 \mathrm{mg} /$ dia, via oral, por 10 dias, ocitocina 20 UI TID, seguida de massagem no úbere e ordenha do conteúdo acumulado a fim de estimular a lactação. A potra apresentava os tendões relaxados e dificuldade em locomover-se. Optou-se por fornecer, em mamadeira, 200 ml de colostro a cada hora nas próximas 12 horas, seguindo com sucedâneo até que a égua iniciasse a produção de leite. Foi realizada imunização passiva com 1 litro de soro hiperimune e iniciou-se o tratamento com ceftiofuor 7,5 mg/Kg BID e amicacina $10 \mathrm{mg} / \mathrm{Kg}$ BID. Cerca de 48 horas após o parto, a potra apresentou depressão, letargia, perda do reflexo de sucção e conseguia ficar em estação apenas com ajuda. Suspeitando-se que a 
potra apresentava síndrome do mau ajustamento, iniciou-se suplementação com oxigenoterapia 5 litros/ min, alopurinol $40 \mathrm{mg} / \mathrm{Kg}$ dose única, gabapentina $20 \mathrm{mg} / \mathrm{Kg}$ TID e finasterida $15 \mathrm{mg} /$ dia por três dias. A alimentação foi realizada por sonda nasogástrica de potros, a cada duas horas, com 200 ml de solução à base de Potromilk ${ }^{\circledR}$. Após 2 dias de tratamento intensivo, o animal começou a apresentar melhoras clínicas, permanecendo em estação e alerta, porém começou a apresentar grande quantidade de refluxo na sonda. Quatro dias após o parto, a potra começou a apresentar abaulamento abdominal e acúmulo excessivo de gás, sendo possível auscultação de timbre metálico durante a percussão auscultatória. Durante exame ultrassonográfico toracoabdominal, observou-se loops de intestino delgado com grande quantidade de líquido e redução da motilidade intestinal. Durante o exame físico, auscultou-se borborigmos em região torácica, taquicardia e taquipnéia. 0 proprietário optou pela não realização da laparotomia exploratória devido ao alto grau de debilidade do paciente. Cinco dias após o parto, a potra veio a óbito, sendo observada hérnia diafragmática com acometimento de $40 \%$ do intestino delgado, além de retroflexão da flexura pélvica. Considerando o elevado e laborioso trabalho de patro, acredita-se que o animal tenha sofrido asfixia neonatal, o que desencadeou a síndrome do mau ajustamento. A elevada força de tração realizada na propriedade durante o parto ocasiou o prolapso uterino e provavelmente tenha sido o fator determinante para a apresentação da hérnia diafragmática no potro. Casos de distocia em equinos, apesar de raros, devem ser tratados com muito cuidado e a monitoração pós-parto da parturiente e do neonato deve ser intensiva, uma vez que diversas patologias podem vir a afetar a égua e o potro.

Palavras-chave: Equino. Asfixia neonatal. Distocia. 